\title{
RECOVERY OF DNA OF GIARDIA INTESTINALIS CYSTS FROM SURFACE WATER CONCENTRATES MEASURED WITH PCR AND REAL TIME PCR
}

\author{
ADAMSKA M.*, LEOŃSKA-DUNIEC A.*, MACIEJEWSKA A.*, SAWCZUK M.* \& SKOTARCZAK B.*
}

\section{Summary:}

The most important restriction for the detection in water samples is the low concentration of Giardia intestinalis cysts, additional difficulty is the presence of PCR inhibitors. We have carried out trials in order to assess the sensitivity of semi-nested PCR and TaqMan real time PCR on the basis of DNA extracted from $G$. intestinalis cysts coming from spiked environmental and distilled water samples, filtrated with the use of Filta-Max ${ }^{\circledR}$ equipment (1623 Method). Removal of inhibitors was carried out with addition of BSA in different concentrations. During the filtration and concentration of water samples, losses of cysts have been recorded. Moreover, addition of BSA to the PCR and real time PCR mix increases the sensitivity of reaction. The optimal concentration of BSA for semi-nested PCR was 15 and $20 \mathrm{ng} / \mu \mathrm{l}$, whereas for real time PCR $5 \mathrm{ng} / \mu \mathrm{l}$.

KEY WORDS: DNA extraction, Giardia intestinalis, PCR, real time PCR
Résumé : AMPLIFICATION PAR PCR ET PCR EN TEMPS RÉEL D'ADN DE KYSTES DE GIARDIA INTESTINALIS CONCENTRÉS EN EAU DE SURFACE La faible concentration des kystes de Giardia intestinalis dans les prélèvements d'eau de surface, ainsi que la présence d'inhibiteurs de la PCR constituent un handicap pour la détection du parasite. Nous avons effectué une série d'essais afin de tester la sensibilité de la PCR semi-nichée et la TaqMan PCR en temps réel dans la détection de l'ADN extrait de kystes de G. intestinalis. Ces kystes proviennent d'échantillons d'eau distillée et d'eau d'environnement, filtrés avec le Filta-Max ${ }^{\circledR}$ (1623 Method). Les inhibiteurs ont été éliminés par la BSA utilisée à différentes concentrations. Des pertes de kystes ont été constatées lors des opérations de filtration et de concentration. L'addition de BSA augmente la sensibilité de la réaction. La concentration optimale de BSA était de 15 et $20 \mathrm{ng} / \mathrm{ul}$ pour la $P C R$ semi-nichée et de $5 \mathrm{ng} / \mu \mathrm{l}$ pour la $P C R$ en temps réel.

MOTS-CLÉS : détection d'ADN, Giardia intestinalis, $P C R, P C R$ en temps réel.

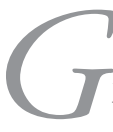
Tiardia intestinalis is an intestinal unicellular parasite causing diarrhea in humans worldwide. The transmission occurs mainly through water contaminated with Giardia cysts (CastroHermida et al., 2008; Haque et al., 2007). Giardiasis is generally self-limiting and asymptomatic in healthy individuals; however, the infection may be a serious health risk for immunocompromised individuals and for children. Although giardiasis is a serious public health problem, the diagnosis of this disease is not routinely approved (Thompson, 2004).

In order to improve the monitoring of Giardia cysts in water, the United States Environmental Protection Agency introduced the 1623 Method (EPA, 2005). This method, used to determine the presence and concentration of cysts in water, is based on microscopic detection; however, more sensitive methods are required for the detection of the very low concentrations of the parasite in water and the identification of the species (Guy et al., 2003). Molecular methods

\footnotetext{
* Department of Genetics, University of Szczecin, ul. Felczaka 3c, 71-412 Szczecin, Poland.

Correspondence: Bogumila Skotarczak.

E-mail: boskot@univ.szczecin.pl
}

give such possibilities, but substances contained in water samples can be potential inhibitors in tests based on DNA.

In an anterior study, we evaluated the efficiencies of different DNA extraction methods (Adamska et al., 2010). In the present study, we have carried out trials to assess the sensitivity of semi-nested PCR and TaqMan real time PCR on the basis of DNA extracted from $G$. intestinalis cysts providing from spiked environmental and distilled water samples. Moreover, the addition of BSA in different concentrations was applied to remove inhibitors.

\section{MATERIALS AND METHODS}

\section{DNA ISOLATION FROM SPIKED WATER SAMPLES}

amples containing $8 \times 10^{5}$ cysts of $G$. intestinalis (Bulk Stock Live, BTF Biomérieux, Australia) in $\checkmark$ PBS were used for DNA extraction. Spiked samples were prepared by adding solutions containing about $8 \times 10^{5}$ cysts in 101 of distilled water, and in 101 of environmental water (Glebokie Lake). They were subjected to this procedure with Manual Filta-Max ${ }^{\circledR}$ 
Wash Station (IDEXX, USA), according to the manufacturer's instructions. $300 \mu \mathrm{l}$ of eluate were collected for the extraction as described previously (Adamska et al., 2010).

\section{Semi-nested PCR and TaqMan Real time PCR AMPLIFICATION}

A region of the $\beta$-giardin gene was amplified by semi-nested PCR protocol described by Caccio et al. (2002). PCR mixture and thermal-time profiles were described previously by Adamska et al. (2010) and Castro-Hermida et al. (2008), respectively. Additionaly, bovine serum albumin (BSA) was added to PCR mix in concentrations: $0,5,10,15,20,50,100,200$ and $400 \mathrm{ng} / \mu \mathrm{l}$. Negative control mixtures contained sterile distilled water in place of DNA. PCR products were visualized by $1.5 \%$ agarose gel electrophoresis. All analyses were carried out in four replicates.

A region of the small subunit rRNA gene of G. intestinalis was used as a target sequence for TaqMan real time PCR (Haque et al., 2007). PCR mixture and thermal-time profiles were the same as described by Adamska at al. (2010) and Haque et al. (2007), respectively. Additionaly, BSA was added to PCR mix in concentrations: $0,5,10,15,20,50,100,200$ and $400 \mathrm{ng} / \mu \mathrm{l}$. Appropriate negative controls were included in each PCR run. All analysis were carried out in four replicates.

\section{RESULTS AND DISCUSSION}

T The intensity of signal obtained with semi-nested PCR was similar for isolates received from filtration of spiked distilled and lake water, whereas intensity was higher when isolates were directly received from $G$. intestinalis cysts in PBS. The seminested PCR results have been confirmed by TaqMan real time PCR in form of adequate $\mathrm{C}_{\mathrm{T}}$ values, which were similar in isolates from distilled $(22.21 \pm 0.34)$ and lake $(24.38 \pm 0.49)$ water, whereas $C_{T}$ values for isolates from $G$. intestinalis cysts in PBS were lower $(16.14 \pm 0.23)$.
Addition of BSA to PCR mix for samples isolated from spiked lake water caused an increase in reaction sensitivity. For semi-nested PCR, we obtained very strong intensity of DNA bands for 15 and $20 \mathrm{ng} / \mu \mathrm{l}$, strong for 5,10 and $50 \mathrm{ng} / \mu \mathrm{l}$, medium for $0 \mathrm{ng} / \mu \mathrm{l}$ and weak for $100 \mathrm{ng} / \mu \mathrm{l}$. There were no PCR signals for 200, 300 and $400 \mathrm{ng} / \mu \mathrm{l} . \mathrm{C}_{\mathrm{T}}$ values for real time PCR with addition of BSA are shown in Fig. 1.

Earlier studies have shown various degrees of recovery efficiency for Giardia and noted a decrease in the recovery level of cysts after filtration (Wohlsen et al., 2004). In our study, losses of Giardia cysts were also recorded during the filtration of spiked distilled and lake water samples. The intensity of signal obtained with semi-nested PCR method was similar for isolates received from filtration of spiked distilled and lake water, whereas in case isolates received directly from G. intestinalis cysts in PBS, the intensity was higher. The semi-nested PCR results have been confirmed by real time PCR results in form of adequate $C_{T}$ values.

The environmental samples are rich in PCR inhibitors which could be co-extracted with DNA and which could interfere with the PCR amplification (Jiang et al., 2005; Schriewer et al., 2011). According to the 1623 Method, the next step after concentration of Giardia cysts is the immunomagnetic separation (IMS) that should eliminate the inhibitors (USEPA 2005). However, this method becomes impractical for organisms that have no IMS procedure, and is also expensive (Jiang et al., 2005). Many chemicals are used to deactivate PCR inhibitors, e.g. bovine serum albumin (BSA) that is one of the most efficient facilitators. BSA has been widely used to reduce inhibitory effects in conventional PCR assays of protozoan, however, studies reporting optimization of BSA concentrations for real time PCR are rare (Jiang et al., 2005; Schriewer et al., 2011).

Many different BSA concentrations were used in earlier studies (from 20 to $400 \mathrm{ng} / \mu \mathrm{l}$ ) (Jiang et al., 2005; Schriewer et al., 2011). Studies of Guy et al. (2003) revealed that addition of BSA in concentration $20 \mathrm{ng} / \mu \mathrm{l}$ to the real time PCR mixture removed the inhibitory effect. In our study, addition of BSA to PCR mix for

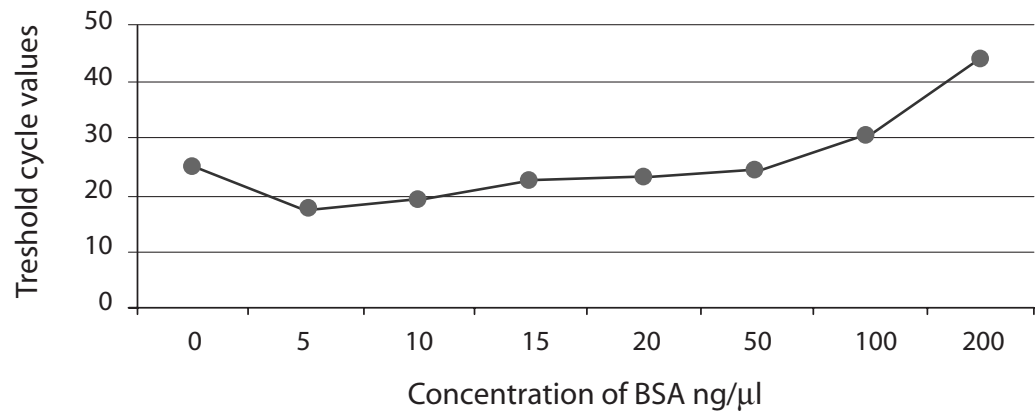

Fig. 1. - Correlation between $\mathrm{C}_{\mathrm{T}}$ values and BSA concentrations for TaqMan real time PCR. 
samples isolated from spiked lake water caused an increase in reaction sensitivity, but only at low concentrations. For semi-nested PCR, the optimal concentration of BSA was 15 and $20 \mathrm{ng} / \mu \mathrm{l}$, whereas for TaqMan real time PCR $5 \mathrm{ng} / \mu \mathrm{l}$. Our studies revealed that high concentration of BSA (100 ng/ $\mu \mathrm{l}$ and above) has an inhibiting effect on the PCR. Schriewer et al. (2011) obtained similar results. However, according to Jiang et al. (2005), the effect of PCR inhibitors was significantly reduced with $400 \mathrm{ng} / \mu \mathrm{l}$. The optimum range of applied BSA may vary depending on the amount of inhibitors and the matrix composition (Schriewer et al., 2011), so the origin of environmental sample and type of detected organism may affect optimum BSA concentration.

\section{ACKNOWLEDGEMENTS}

his study was supported in part by the Ministry of Science and Higher Education, grant no. N N404 248635 .

\section{REFERENCES}

Adamska M., Leońska-Duniec A., Maciejewska A., Sawczuk M. \& SKOTARCZAK B. Comparison of efficiency of various DNA extraction methods from cysts of Giardia intestinalis measured by PCR and TaqMan real time PCR. Parasite, 2010, 17, 299-305.

Cacciò S.M., De Giacomo M. \& Pozio E. Sequence analysis of the beta-giardin gene and development of a polymerase chain reaction-restriction fragment length polymorphism assay to genotype Giardia duodenalis cysts from human faecal samples. International Journal of Parasitology, 2002, 32 (8), 1023-1030.

Castro-Hermida J.A., García-Presedo i., Almeida A., GonzálezWarleta M., Correia Da Costa J.M. \& Mezo M. Presence of Cryptosporidium spp. and Giardia duodenalis through drinking water. Science of the Total Environment, 2008, 405 (1-3), 45-53.

EPA - U.S. EnVironmental Protection Agency. Method 1623: Cryptosporidium and Giardia in water by Filtration/IMS/ FA, in: U.S. Environmental Protection Agency publication no. 815-R-05-002. EPA, Washington, D.C., 2005.

Guy R.A., Payment P., Krull U.J. \& Horgen P.A. Real-Time PCR for quantification of Giardia and Cryptosporidium in environmental water samples and sewage. Applied and Environmental Microbiology, 2003, 69 (9), 5178-5185.

Haque R., Roy S., Siddique A., Mondal U., Rahman S.M., Mondal D., Houpt E. \& Petri W.A. Jr. Multiplex real-time PCR assay for detection of Entamoeba histolytica, Giardia intestinalis, and Cryptosporidium spp. American Journal of Tropical Medicine and Hygiene, 2007, 76 (4), 713-717.

Jiang J., Alderisio K.A., Singh A. \& XiaO L. Development of procedures for direct extraction of Cryptosporidium DNA from water concentrates and for relief of PCR inhibitors. Applied and Environmental Microbiology, 2005, 71 (3), 1135-1141.

SChriewer A., Wehlmann A. \& Wuertz S. Improving qPCR efficiency in environmental samples by selective removal of humic acids with DAX-8. Journal of Microbiological Methods, 2011, 85, 16-21.

Thompson R.C. The zoonotic significance and molecular epidemiology of Giardia and giardiasais. Veterinary Parasitology, 2004, 126, 15-35.

Wohlsen T., Bates J., Gray B. \& Katouli M. Evaluation of five membrane filtration methods for recovery of Cryptosporidium and Giardia isolates from water samples. Applied and Environmental Microbiology, 2004, 70 (4), 2318-2322.

Received on February $14^{\text {th }}, 2011$ Accepted on June 22 ${ }^{\text {nd }}, 2011$ 